\title{
The use of repetitive element PCR fingerprinting (rep-PCR) for genetic subtyping of German field isolates of Paenibacillus larvae subsp. larvae
}

\author{
Elke GENERSCH ${ }^{\mathrm{a} *}$, Christoph OTTEN ${ }^{\mathrm{b}}$ \\ ${ }^{a}$ Länderinstitut für Bienenkunde, Friedrich-Engels-Str. 32, 16540 Hohen Neuendorf, Germany \\ b Staatliche Lehr- und Versuchsanstalt für Landwirtschaft, Wein- und Gartenbau, Im Bannen 38-54, \\ 56727 Mayen, Germany
}

(Received 7 June 2002; revised 12 September 2002; accepted 18 September 2002)

\begin{abstract}
Studies using the repetitive element PCR fingerprinting technique (rep-PCR) revealed that BOX A1R-, MBO REP1- and ERIC-primers reproducibly generate distinctive DNA fingerprints from Paenibacillus larvae subsp. larvae. Four different genetic subtypes of $P$. larvae were identified in Germany using the three primers. Correlating the results from genetic and morphological subtyping, the flat and transparent morphotype could be assigned to one genetic group. Geographic evaluation of our results demonstrated that the different genetic subtypes appeared in clusters correlating with different outbreaks of American foulbrood. Taken together, our results indicated that rep-PCR performed with a combination of BOX A1R- and MBO REP1-primers will be an effective tool for establishing a molecular epidemiology of P. l. larvae.
\end{abstract}

American foulbrood / Paenibacillus larvae larvae / DNA-fingerprinting / genetic subtyping / molecular epidemiology

\section{INTRODUCTION}

American foulbrood (AFB), caused by the spore-forming, Gram-positive bacterium Paenibacillus larvae subsp. larvae (P. l. larvae) (Heyndrickx et al., 1996), is the most serious bacterial disease of honeybee brood. The oval-shaped spores represent the infectious stage of $P$. $l$. larvae. Since antibiotics do not affect the spores, no, treatment that actually cures AFB is available to date. Antibiotics used in some countries only mask the disease. By killing the vegetative forms of the bacterium, clinical symptoms are suppressed but the spores accumulate in the hive.
AFB has spread around the world causing considerable economic loss to beekeepers. Despite this situation, the epidemiology of AFB, especially the molecular epidemiology, has received comparatively little attention (for review: Chantawannakul and Dancer, 2001).

Epidemiological studies investigate the time and spatial distribution of infectious diseases and attempt to reveal the factors influencing outbreaks. Outbreaks of infectious disease often result from exposure to a common source of the causative agent. In epidemiological terms, the organisms causing an outbreak are clonally related and share biochemical traits and genomic characteristics. The process

\footnotetext{
* Correspondence and reprints

E-mail: elke.genersch@rz.hu-berlin.de
} 
of subtyping, therefore, is important epidemiologically in determining the source of the infection, recognizing particularly virulent strains, and monitoring control programs. The shortcomings of phenotypically based typing methods have led to the development of molecular typing methods based on the microbial DNA sequence. A number of analytical methods for differentiating between subtypes or strains of bacteria have been evaluated. These methods include. pulsed-field gel electrophoresis, PCR-based locus-specific RFLP, repetitive element PCR fingerprinting (repPCR), random amplified polymorphic DNA (RAPD), and sequencing. A suitable typing method must have high discrimination power combined with good to moderate inter- and intra-laboratory reproducibility. In addition, it should be easy to set up, to use and to interpret. All of these requirements are fulfilled by the rep-PCR used in this study (Olive and Bean, 1999).

With the rep-PCR, it is possible to fingerprint bacterial genomes by examining strainor subtype-specific patterns obtained from PCR amplification of repetitive DNA elements present within the bacterial genome. There are three main sets of repetitive DNA elements used for typing purposes. The repetitive extragenic palindromic (REP) elements are palindromic units, which contain a variable loop in the proposed stem-loop structure (Stern et al., 1984). ERIC sequences are characterized by central, conserved palindromic structures (Hulton et al., 1991). BOX elements consist of differentially conserved subunits, namely boxA, boxB, and boxC (Martin et al., 1992). Only the boxA-like subunit sequences appear highly conserved among diverse bacteria (Versalovic et al., 1994). BOX elements were the first repetitive sequences identified in a Gram-positive organism (Streptococcus pneumoniae) (Martin et al., 1992). REP- and ERIC-sequences were originally identified in Gram-negative bacteria and then found to be conserved in all related Gram-negative enteric bacteria and in many diverse, unrelated bacteria from multiple phyla (Versalovic et al., 1994; Olive and Bean, 1999).

In two recent studies, restriction fragment length polymorphism (RFLP) analysis was used to differentiate between different isolates of P. l. larvae (Djordjevic et al., 1994) or
Paenibacillus alvei ( $P$. alvei) (Djordjevic et al., 2000). CfoI-generated whole-cell DNA profiles that showed a very high degree of heterogeneity for both $P$. alvei and $P$. l. larvae, made it difficult to convincingly define clonal isolates. Since bacterial epidemiology is reliant on the precise determination of clonal isolates, RFLP analysis does not appear to be suitable for molecular epidemiology of Paenibacillus.

In this paper, we describe the use of the repPCR DNA fingerprinting technique to differentiate $P$. $l$. larvae subtypes isolated from several AFB outbreaks from different geographical regions of Germany between 1998 and 2002. The rep-PCR technique was chosen because this technique is simple, can differentiate between closely related strains of bacteria and shows good reproduciblity. Rep-PCR has been applied successfully in the classification and differentiation of strains of many Grampositive and -negative bacteria. We also evaluated the colony morphology of the field isolates of $P$. l. larvae and correlated these results with those obtained from DNA fingerprinting.

\section{MATERIALS AND METHODS}

\subsection{Bacterial isolates}

From foulbrood monitoring programs offered in various regions in Germany (Fig. 4), more than 1500 honey samples were collected close to the brood nest. All samples were sent in between 1998 and 2002 from beekeepers taking part in these programs on a voluntary basis. The samples were analyzed for $P$. l. larvae spores. Hives with $P$. l. lar$v a e$-positive honey samples were further investigated for clinical signs of AFB. A total of 105 P. $l$. larvae isolates (Tab. I, Fig. 4), corresponding to various outbreaks of AFB diagnosed in the course of these programs, were taken for the epidemiological studies.

\subsection{Bacterial culture}

Honey samples were stored at $4{ }^{\circ} \mathrm{C}$ until they were cultured on bacterial plates. Culture of $P . l$. larvae from honey samples was performed according to standard methods (Hornitzky and Clark, 1991). Briefly, for growth of spore-forming bacteria, honey samples were solubilised over night at $37^{\circ} \mathrm{C}$. Subsequently samples were diluted in bi-distilled water to obtain a $50 \%(\mathrm{w} / \mathrm{v})$ honey solution. 
Table I. Note. All strains were isolated from honey samples originating from outbreaks of AFB in Germany. Geographic origins are given as postal codes. Different morphotypes were defined after cultivation for at least 6 days on Columbia sheep blood agar (CSA). The normal morphotype I is characterized by a greyish-white colour, griddy surface, and a konvex shape. Morphotype II, in contrast, is characterized by an absolutely flat morphology (nearly twodimensional) combined with a colourless, transparent appearance.

\begin{tabular}{|c|c|c|c|c|}
\hline Probe number & German postal code & Year of AFB outbreak & Genotype & Morphotype on CSA \\
\hline 98-0299 & 54518 & 1998 & $\mathrm{AB}$ & 1 \\
\hline $98-0300$ & 54518 & 1998 & $A B$ & 1 \\
\hline $98-0301$ & 54518 & 1998 & $\mathrm{AB}$ & 1 \\
\hline $00-0046$ & 10555 & 2000 & $A B$ & $\mathrm{I}$ \\
\hline $00-0087$ & 06484 & 2000 & $a b$ & II \\
\hline 00-0105 & 06484 & 2000 & $A b$ & I \\
\hline $00-0272$ & 06618 & 2000 & $a b$ & II \\
\hline $00-0502$ & 53604 & 2000 & $A B$ & I \\
\hline $00-0745$ & 41466 & 2000 & $A B$ & 1 \\
\hline $00-0746$ & 41466 & 2000 & $A B$ & I \\
\hline $00-0775$ & 45143 & 2000 & $A B$ & I \\
\hline $00-0777$ & 45359 & 2000 & $A B$ & 1 \\
\hline $00-0778$ & 45357 & 2000 & $A B$ & I \\
\hline 00-0779 & 45356 & 2000 & $A B$ & I \\
\hline $00-0780$ & 45359 & 2000 & $A B$ & I \\
\hline $00-0838$ & 53604 & 2000 & $A B$ & 1 \\
\hline $00-0936$ & 41464 & 2000 & $A B$ & I \\
\hline $00-1032$ & 53604 & 2000 & $A B$ & 1 \\
\hline $00-1111$ & 53175 & 2000 & $A B$ & I \\
\hline $00-1163$ & 53227 & 2000 & $A B$ & I \\
\hline $00-1214$ & 53639 & 2000 & $A B$ & I \\
\hline $00-1229$ & 53639 & 2000 & $A B$ & I \\
\hline $00-1292$ & 53227 & 2000 & $A B$ & I \\
\hline $00-1318$ & 53639 & 2000 & $A B$ & I \\
\hline 00-1391 & 53639 & 2000 & $A B$ & I \\
\hline $00-1410$ & 53567 & 2000 & $A B$ & I \\
\hline $00-1475$ & 53639 & 2000 & $A B$ & I \\
\hline $00-1794$ & 53577 & 2000 & $A B$ & 1 \\
\hline $00-1802$ & 53567 & 2000 & $A B$ & I \\
\hline 00-1805 & 53567 & 2000 & $A B$ & 1 \\
\hline 01-000E & 38667 & 2001 & $A b$ & 1 \\
\hline $01-000 \mathrm{~F}$ & 38350 & 2001 & $a b$ & II \\
\hline $01-0000$ & 29221 & 2001 & $A B$ & I \\
\hline 01-0145 & 06618 & 2001 & $a b$ & II \\
\hline 01-0170 & 06727 & 2001 & $a b$ & II \\
\hline $01-0247$ & 10365 & 2001 & $a b$ & II \\
\hline $01-0248$ & 10365 & 2001 & $a b$ & II \\
\hline 01-0249 & 10365 & 2001 & $a b$ & II \\
\hline $01-0281$ & 06128 & 2001 & $a b$ & II \\
\hline 01-0282 & 06128 & 2001 & $a b$ & II \\
\hline $01-0283$ & 06128 & 2001 & $a b$ & II \\
\hline 01-0289 & 06917 & 2001 & $A b$ & I \\
\hline $01-0290$ & 06917 & 2001 & $A b$ & 1 \\
\hline $01-0292$ & 06917 & 2001 & $A b$ & I \\
\hline $01-0293$ & 06917 & 2001 & $A b$ & I \\
\hline 01-0337 & 76846 & 2001 & $a b$ & II \\
\hline 01-0342 & 76846 & 2001 & $A B$ & I \\
\hline 01-0348 & 76846 & 2001 & $a b$ & II \\
\hline $01-0358$ & 06917 & 2001 & $A b$ & I \\
\hline $01-0363$ & 06917 & 2001 & $A b$ & 1 \\
\hline 01-0402 & 06922 & 2001 & $a b$ & II \\
\hline $01-0440$ & 06922 & 2001 & $A b$ & I \\
\hline
\end{tabular}


Table I. continued.

\begin{tabular}{|c|c|c|c|c|}
\hline Probe number & German postal code & Year of AFB outbreak & Genotype & Morphotype \\
\hline $01-0448$ & 03096 & 2001 & $A B$ & 1 \\
\hline $01-0454$ & 04838 & 2001 & $a b$ & II \\
\hline $01-0455$ & 04838 & 2001 & $a b$ & II \\
\hline $01-0456$ & 04838 & 2001 & $a b$ & II \\
\hline $01-0457$ & 06917 & 2001 & $A b$ & I \\
\hline $01-0510$ & 53639 & 2001 & $A B$ & I \\
\hline $01-0550$ & 53639 & 2001 & $A B$ & I \\
\hline 01-0552 & 53639 & 2001 & $A B$ & I \\
\hline 01-0649 & 53173 & 2001 & $A B$ & I \\
\hline 01-0659 & 53639 & 2001 & $A B$ & I \\
\hline 01-0910 & 53639 & 2001 & $A B$ & I \\
\hline 01-0990 & 54689 & 2001 & $A B$ & I \\
\hline 01-0997 & 54689 & 2001 & $A B$ & I \\
\hline 01-1021 & 54867 & 2001 & $A B$ & I \\
\hline $01-1028$ & 54867 & 2001 & $A B$ & I \\
\hline $01-1100$ & 53577 & 2001 & $A B$ & I \\
\hline 01-1101 & 53577 & 2001 & $A B$ & I \\
\hline 01-1154 & 54597 & 2001 & $A B$ & I \\
\hline $01-1173$ & 53639 & 2001 & $A B$ & I \\
\hline 01-1303 & 53639 & 2001 & $A B$ & I \\
\hline 01-1706 & 76846 & 2001 & $a b$ & II \\
\hline 01-1707 & 76846 & 2001 & $a b$ & II \\
\hline 01-1709 & 76846 & 2001 & $a b$ & II \\
\hline 01-1712 & 76846 & 2001 & $a b$ & II \\
\hline 01-1713 & 76846 & 2001 & $a b$ & II \\
\hline 01-1714 & 76846 & 2001 & $A B$ & I \\
\hline $01-1860$ & 54619 & 2001 & $A B$ & I \\
\hline 01-1866 & 54619 & 2001 & $A B$ & 1 \\
\hline $02-0009$ & 23568 & 2002 & $\alpha B$ & I \\
\hline $02-0060$ & 06917 & 2002 & $\mathrm{Ab}$ & I \\
\hline $02-0065$ & 06917 & 2002 & $A b$ & I \\
\hline $02-0066$ & 06917 & 2002 & $A b$ & I \\
\hline $02-0067$ & 06917 & 2002 & $A b$ & I \\
\hline $02-0068$ & 06917 & 2002 & $A b$ & I \\
\hline $02-0070$ & 06917 & 2002 & $A b$ & I \\
\hline $02-0075$ & 06917 & 2002 & $A b$ & I \\
\hline $02-0079$ & 06917 & 2002 & $A b$ & I \\
\hline $02-0080$ & 06917 & 2002 & $A b$ & I \\
\hline $02-0081$ & 06917 & 2002 & $A b$ & I \\
\hline $02-0083$ & 06917 & 2002 & $A b$ & I \\
\hline 02-0109 & 06917 & 2002 & $A b$ & I \\
\hline 02-0113 & 06917 & 2002 & $A b$ & I \\
\hline $02-0114$ & 06917 & 2002 & $A b$ & I \\
\hline $02-0117$ & 06917 & 2002 & $A b$ & I \\
\hline $02-0120$ & 06917 & 2002 & $A b$ & I \\
\hline $02-0121$ & 06917 & 2002 & $A b$ & I \\
\hline $02-0122$ & 06917 & 2002 & $A b$ & I \\
\hline 02-0124 & 06917 & 2002 & $A b$ & I \\
\hline $02-0127$ & 06785 & 2002 & $a b$ & II \\
\hline $02-0128$ & 06785 & 2002 & $a b$ & II \\
\hline $02-0129$ & 06785 & 2002 & $a b$ & II \\
\hline $02-0130$ & 06785 & 2002 & $a b$ & II \\
\hline $02-0141$ & 04838 & 2002 & $a b$ & II \\
\hline
\end{tabular}


To select for spores, samples were incubated at $90{ }^{\circ} \mathrm{C}$ for $6 \mathrm{~min}$. Samples were allowed to cool down at room temperature prior to plating them (200 $\mu \mathrm{L} /$ plate) onto Columbia sheep blood agar plates. Three plates were prepared from each sample. Plates were incubated at $37^{\circ} \mathrm{C}$ and evaluated for bacterial growth after 3 and 6 days. After 6 days, $P$. l. larvae-like colonies were identified by Plagemann- and catalase tests as well as by specific PCR-detection.

\subsection{Identification of $P$. $l$. larvae colonies}

Colonies with a $P$. l. larvae-like morphology were further analysed by Plagemann- and catalasetests. For the Plagemann-test (Plagemann, 1985), the liquid part of Columbia sheep blood agar slants was inoculated with part of the bacterial colony in question. The tube was sealed with Parafilm so as to be air tight, and incubated at $37{ }^{\circ} \mathrm{C}$ for 10 days. Subsequently, the liquid part was analysed for the presence of spores and giant whips by phase contrast microscopy. For the catalase test, part of the colony in question was transferred to a microscopic slide using a wooden stick and mixed with a drop of $30 \% \mathrm{H}_{2} \mathrm{O}_{2}$. Production of air bubbles is indicative of catalase activity, whereas no air bubbles indicates a lack of catalase activity. $P . l$. larvae is characterised by a lack of catalase activity and the occurrence of giant whips upon sporulation (Ritter, 1996; Hansen and Brodsgaard, 1999).

For PCR identification of bacterial colonies grown on agar plates, part of the colony in question was re-suspended in $50 \mu \mathrm{L}$ bi-distilled water and subsequently incubated at $90{ }^{\circ} \mathrm{C}$ for $15 \mathrm{~min}$. Probes were centrifuged at $5000 \mathrm{~g}$ for $10 \mathrm{~min}$. The supernatant containing the DNA was transferred to a new tube and directly used for PCR analysis. PCR analysis was carried out as described previously (Govan et al., 1999; Dobbelaere et al., 2001).

\subsection{Preparation of bacterial DNA for PCR DNA fingerprinting}

For preparation of $P$. l. larvae-DNA suitable for rep-PCR DNA fingerprinting, an isolated colony was scraped off the agar plate and resuspended in $200 \mu \mathrm{L}$ bi-distilled water. The sample was centrifuged for $2 \mathrm{~min}$ at $10000 \mathrm{rpm}$ and the bacterial pellet was re-suspended in $150 \mu \mathrm{L}$ of $6 \%$ InstaGene matrix (Biorad). The sample was then incubated at $56{ }^{\circ} \mathrm{C}$ for $20 \mathrm{~min}$, vortexed at high speed for $10 \mathrm{~s}$, placed in a boiling water bath for another $20 \mathrm{~min}$ and again vortexed at high speed for 10 seconds. The InstaGene matrix was pelleted by centrifugation at $12000 \mathrm{rpm}$ for $8 \mathrm{~min}$. Per PCR reaction $5 \mu \mathrm{L}$ of the supernatant containing the bacterial DNA were used.

\subsection{PCR analysis}

The DNA sequences of the primers used for DNA fingerprinting were as follows (Versalovic et al., 1994):

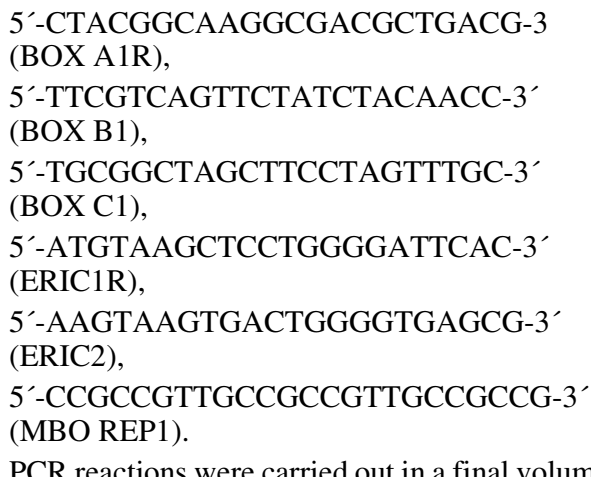

PCR reactions were carried out in a final volume of $25 \mu \mathrm{L}$ consisting of $1 \times$ Qiagen reaction buffer and a final concentration of $2.5 \mathrm{mM} \mathrm{MgCl}_{2}$, $250 \mu \mathrm{M}$ dNTPs (dATP, dCTP, dGTP, dTTP), $10 \mu \mathrm{M}$ primer, and $0,3 \mathrm{U}$ HotStarTaq polymerase (Qiagen). The reaction conditions were as follows: After the initial activation step $\left(15 \mathrm{~min}, 95^{\circ} \mathrm{C}\right)$, 35 cycles at $94{ }^{\circ} \mathrm{C}$ for 1 minute, at $53{ }^{\circ} \mathrm{C}$ for 1 minute, and at $72{ }^{\circ} \mathrm{C}$ for $2.5 \mathrm{~min}$ were run followed by a final elongation step at $72^{\circ} \mathrm{C}$ for $10 \mathrm{~min}$. Five microliters of the PCR reactions were analyzed on a $0.8 \%$ agarose gel. The DNA bands were stained with ethidium bromide and visualized by UV light.

\section{RESULTS}

\subsection{Testing of different repetitive sequence-based oligonucleotide- primers}

Figure 1 shows typical fingerprints for $P$. $l$. larvae isolates generated by rep-PCR performed with primers $\mathrm{BOX} \mathrm{A} 1 \mathrm{R}, \mathrm{BOX} \mathrm{B} 1$, BOX C1, MBO REP1, and ERIC. Complex fingerprint patterns were obtained for all of the isolates studied with primers BOX A1R, MBO REP1, and ERIC. The band patterns of isolates from different geographic origins were very similar and showed only single band differences. The sizes of the PCR products generated with BOX A1R- or ERIC-primers ranged from slightly more or slightly less, respectively, than $500 \mathrm{bp}$ up to several $\mathrm{kB}$. With MBO REP1-primers amplicons were in the size range between $750 \mathrm{bp}$ and several $\mathrm{kB}$. Primers BOX B1 and BOX C1 generated no 


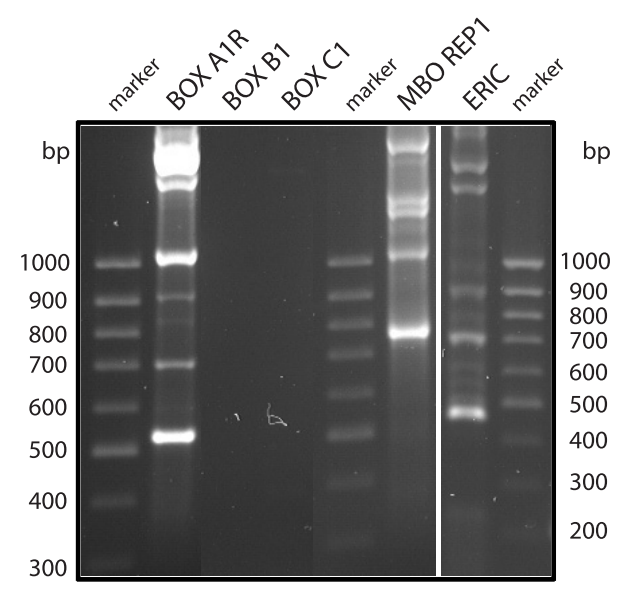

Figure 1. Testing of different repetitive sequencebased oligonucleotide-primers in rep-PCR fingerprinting of $P$. l. larvae. Primers tested were BOX A1R, BOX B1, BOX C1, MBO REP1, and ERIC, as indicated in the figure.

bands at all, making these two primers not suitable for DNA fingerprinting of $P$. l. larvae.

\subsection{Subtyping of $P$. $l$. larvae isolates using BOX A1R- and MBO REP1-primers}

A total of 105 P. l. larvae isolates collected from various outbreaks of AFB in Germany between 1998 and 2002 were used as templates for rep-PCR performed with BOX A1R-, MBO REP1-, and ERIC-primers. While BOX A1R- and MBO REP1-primers always generated high-quality and reliable DNA fingerprints, ERIC-primers did so in only approximately $86 \%$ of the isolates (90 isolates). Figure 2 shows representative BOX, REP- and ERIC-fingerprinting patterns. With BOX A1R-primers, three reproducible patterns were easily distinguishable, differing in showing either no, one or two bands around $700 \mathrm{bp}$, named $a, A$, or $\alpha$, respectively (Fig. 2A). The patterns obtained with MBO REP1- primers fell into two groups, characterized by one band around $1000 \mathrm{bp}$ migrating either slightly more slowly than the $1000 \mathrm{bp}-$ marker band (named $B$ ) or faster (named $b$ )
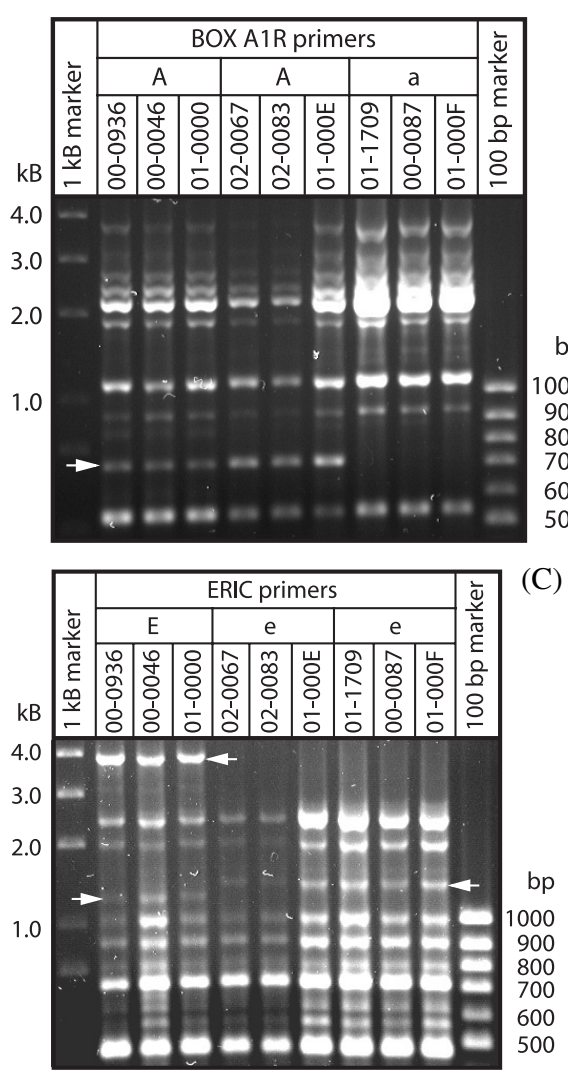
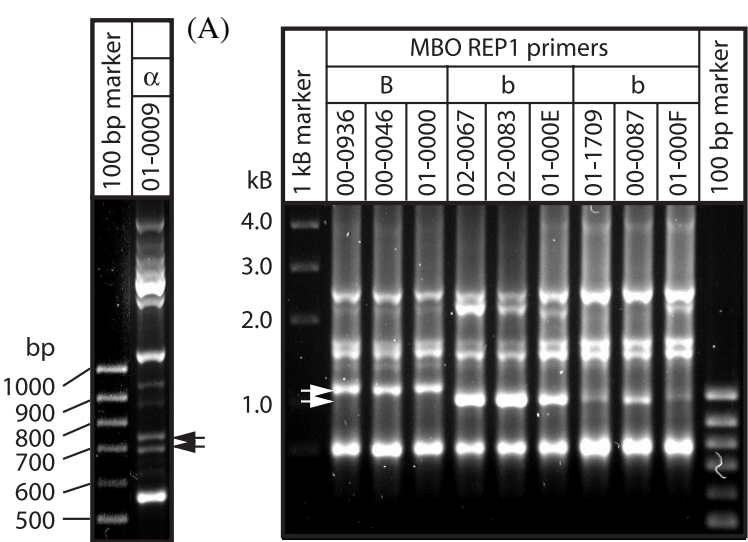

(B)

Figure 2. Characteristic rep-PCR fingerprint patterns of $P$. l. larvae isolated from different geographic regions of Germany. (A) Using BOX A1R primers, isolates of $P$. $l$. larvae were analysed by rep-PCR. Shown are ten representative isolates. Differences in banding pattern between the three subgroups $A, a$, and $\alpha$ are highlighted by arrowheads. (B) Using MBO REP1-primers, isolates of $P$. l. larvae were analysed by rep-PCR. Shown are nine representative isolates. Differences in banding patterns between the two subgroups $B$ and $b$ are highlighted by arrowheads. (C) Using ERIC-primers, isolates of $P$. $l$. larvae were analysed by rep-PCR. Shown are nine representative isolates. Differences in banding patterns between the two subgroups $E$ and $e$ are highlighted by arrowheads. 

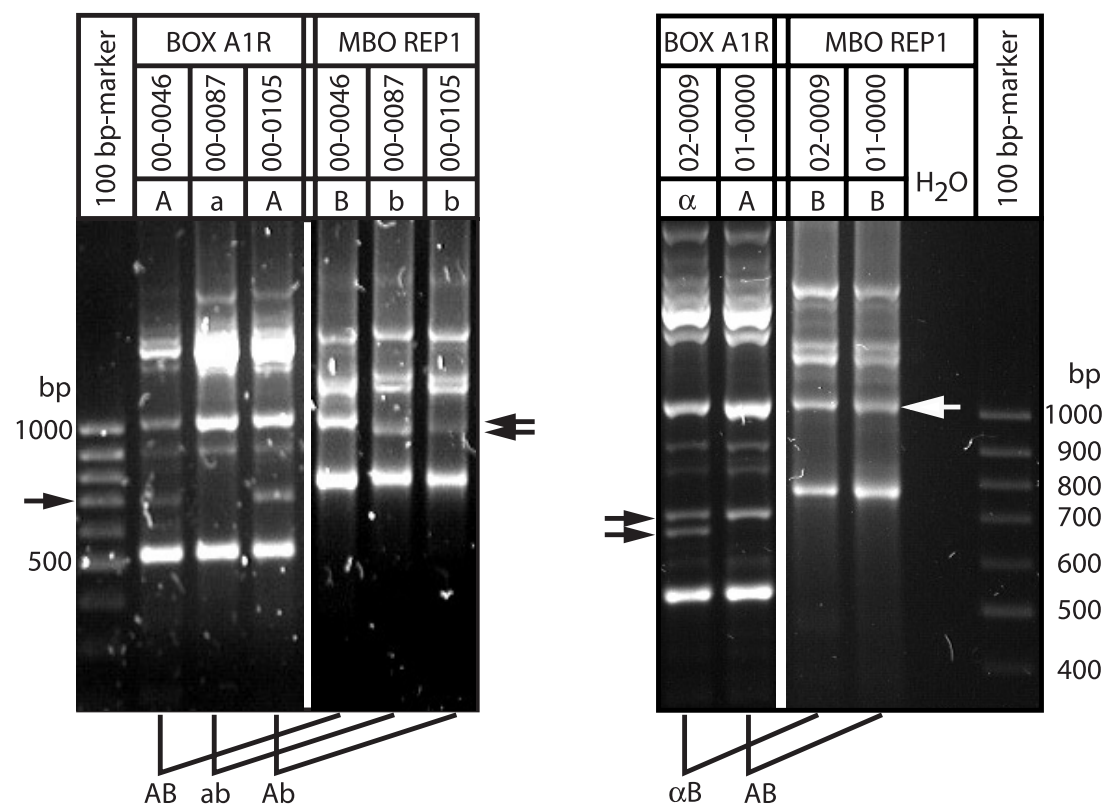

Figure 3. Identification of four genetic subgroups among the $P$. l. larvae population in Germany. $P$. $l$. larvae isolates were analysed by rep-PCR performed with BOX A1R and MBO REP1 primers. Bands differing between the different subgroups are highlighted by arrowheads. Combining the BOX-and REPpatterns obtained for a single isolate revealed four genetic subgroups as indicated in the figure.

(Fig. 2B). With ERIC-primers two genetic subgroups, $E$ and $e$, could be identified showing differences in their banding pattern between $1000 \mathrm{bp}$ and $2000 \mathrm{bp}$. In addition, group $E$ showed one band around $4.0 \mathrm{kB}$ that was missing in group $e$ (Fig. 2C). ERIC-fingerprinting patterns $E$ and $e$ always co-segregated with REP-patterns $B$ and $b$, respectively. In contrast, the three BOX-groups were found in varying combinations with the two REPgroups. Hence, a total of six genetic subgroups based on a combined typing with BOX A1Rand MBO REP1-primers were theoretically possible. Figure 3 shows the four genetic subgroups of $P$. l. larvae identified so far. BOXpattern $A$ could be found in combination with REP-patterns $B$ and $b$, resulting in genetic subgroups $A B$ and $A b$. BOX-pattern $a$ only occurred in combination with REP-pattern $b$, resulting in the genetic subgroup $a b$. The fourth subgroup identified so far, $\alpha B$, resulted from a combination of BOX-pattern $\alpha$ and REP-pattern $B$. Since ERIC-patterns co-segregated with REP-patterns no further discrimination based on the primers used in this study was possible.

\subsection{Correlation between genetic and morphological subtyping}

P. l. larvae colonies grown on Columbia sheep blood agar (CSA) normally show a morphology characterized by a greyish-white colour, griddy surface, and a konvex shape (morphotype I). In contrast, $25.7 \%$ of our isolates exhibited an absolutely flat morphology combined with a colourless, transparent appearance (morphotype II). Nevertheless, they were unambiguously identified as $P$. $l$. larvae by catalase- and Plagemann-tests as well as by specific PCR detection. Table I shows the results from correlating the genetic subgroups of $P$. $l$. larvae with the two different morphotypes. With the isolates examined so far, the normal morphotype (I) could be found in three genetic subgroups $(A B, A b$, and $\alpha B)$, whereas morphotype II could be assigned to the genetic subgroup $a b$.

\subsection{Geographic clustering of genetic subtypes}

The geographic clustering of the different genetic subgroups of $P$. l. larvae is depicted in 


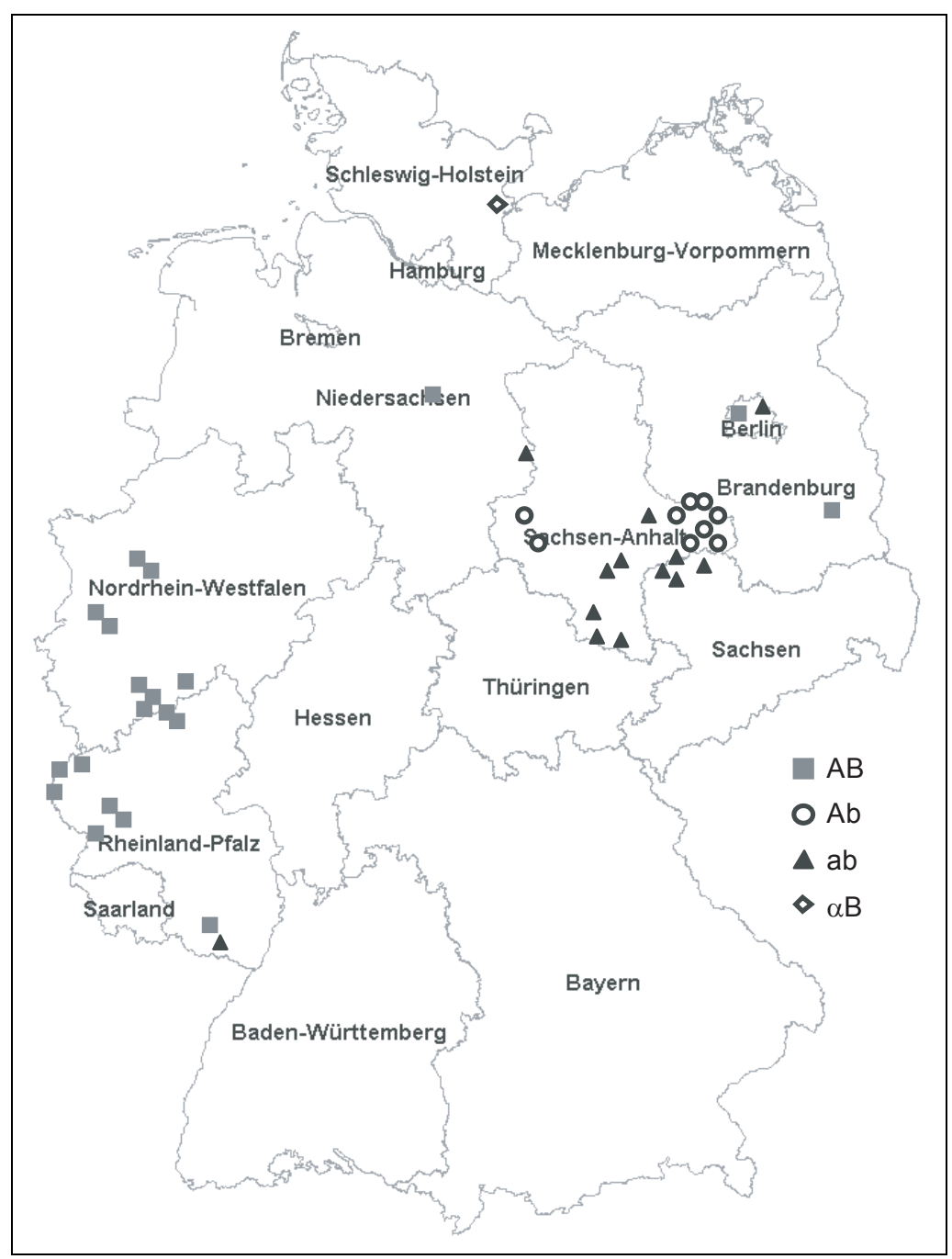

Figure 4. Geographic clustering of the four genetic subgroups $A B, A b, a b$, and $\alpha B$ of $P$. l. larvae isolated from different regions in Germany. The map was created using RegioGraph (Softline) and the corresponding postal codes from each probe (Tab. I).

Figure 4. In the western part of Germany, a group $A B$ was prevalent. Subgroup $a b$ could be identified in only one case in this part of Germany as the etiologic agent. In contrast, subgroup $A B$ could be isolated only in two cases from the eastern part of Germany, while in all other cases the isolates belonged to subgroups $A b$ or $a b$. Subgroup $\alpha B$ could be identified as the causative agent in only one case of AFB outbreak in the northern part of Germany.

\section{DISCUSSION}

In this study, we demonstrated that repPCR DNA fingerprint analysis is a useful tool for differentiating between $P$. l. larvae isolates obtained from different outbreaks of AFB in Germany. We found that the discriminatory power of this method was enhanced when combining BOX- and REP-banding patterns. Adding the DNA fingerprints obtained with ERIC-primers did not result in an increase in 
information. Therefore, rep-PCR performed with BOX A1R- and MBO REP1-primers should be the preferred methodology when establishing a molecular epidemiology for $P$. $l$. larvae.

When the two morphotypes were correlated with the four genotypes from our collection of field isolates of German P. l. larvae strains, the shortcomings of phenotypically based typing methods became obvious. Our results suggested that while morphotype II seemed to be a characteristic for genotype $a b$, morphotype $I$ separated into at least three different genotypes, $A B, A b$, and $\alpha B$. Therefore, molecular subtyping is necessary for establishing a powerful epidemiology for $P$. l. larvae.

Biochemical subtyping of $P$. l. larvae was the first attempt to distinguish among different types of $P$. l. larvae and their relative occurrence in disease outbreaks. Seven strains of $P$. l. larvae were identified differing in their biochemical properties. Variable features used for subtyping included mannitol hydrolysis, production of acid from salicin, and nitrate reduction (Jelinski, 1985). To our knowledge there are no reports showing that biochemical subtyping could be used successfully in tracing the origin of isolates involved in disease outbreaks. For this purpose, a molecular epidemiology based on genetic subtyping seems to be more suitable. To date, very few studies are available on the genetic subtyping of $P . l$. larvae.

In one recent study (Alippi and Aguilar, 1998), different strains of $P$. l. larvae, most of them isolated from Argentina, were analysed by rep-PCR. To determine the origin of $P$. $l$. larvae present in Argentina they also analysed a few strains from USA and Europe. Based on different BOX-banding patterns, three genetic subgroups among the P. l. larvae population in Argentina were identified. According to their results, Germany harbors only one genetic subgroup identical to the one also found in the USA, France and Italy.

Our study was the first to evaluate the genetic variability of $P$. l. larvae present in Germany. Our finding that at least four genetic subgroups are present in Germany is in contrast to the results of Alippi and Aguilar (1998) in which only one genetic subgroup was found in Germany. Their conclusion was based on the analysis of three German isolates originating from a single location, and thus is not considered a representative sample. Based on analysing our field collection of German isolates, we could clearly identify four different genetic subgroups. These subgroups could be assigned to different outbreaks of AFB in Germany.

For subtyping of Argentinian P. l. larvae isolates, Alippi and Aguilar (1998) used BOX A1R-, REP1R.I/REP2-I-, and ERICprimers. They found three subgroups $(A, B$, and $C$ ) differing in their BOX A1R-banding pattern. REP-primers gave the same results. No differences could be observed among patterns generated with primers ERIC.

In our study we found three different BOXpatterns $(A, a$, and $\alpha)$, two REP- patterns (B and $b$ ), based on using MBO REP1- instead of REP1R.I/REP2-I-primers, and two ERIC- patterns $(E$ and $e$ ). ERIC- and REP-patterns always co-segregated, whereas REP- and BOX-patterns occurred in different combinations allowing the identification of a total of four genetic subgroups: $A B(E), A b(e), a b(e)$, and $\alpha B(E)$. Since BOX-subgroup $A$ fell into two ERIC-groups, it cannot correlate with one of the three BOX-defined Argentinian groups characterized by a common ERIC-pattern. BOX-subgroups $a$ and $\alpha$ belong to ERIC-subgroups $e$ and $E$, respectively. Therefore, one of them could correlate with one of the Argentinian subgroups, resulting in at least two newly identified BOX-subgroups. Since the interlaboratory reproducibility of rep-PCR is moderate (Olive and Bean, 1999) and different REP-primers were used, it was not possible to correlate the BOX-typing results and to assign the German isolate, analysed by Alippi and Aguilar (1998), to one of the BOX-subgroups $A, a$, or $\alpha$, as defined in our study.

Overall, our results showed that using only BOX-primers for genetic subtyping of $P$. $l$. larvae did not reveal the full picture. Instead, by combining MBO REP1and BOX-primers the discriminatory power of rep-PCR for typing of $P$. l. larvae could be enhanced.

Geographic clustering and prevalence of different genetic subgroups among the $P$. $l$. larvae population in Germany convincingly showed that genetic subtyping based on 
rep-PCR is a powerful tool for molecular epidemiological studies with $P$. l. larvae. Using MBO REP1/BOX A1R-primers on a routine basis for classifying $P$. $l$. larvae isolates obtained from different outbreaks of AFB will enable detection of cross-transmission, determination of the source of the infection, and monitoring control programs. Further characterisation of the different $P . l$. larvae -subtypes might reveal differences in virulence. It would then be possible to recognize more or less virulent strains of $P . l$. larvae and to adjust the appropriate control measures.

\section{ACKNOWLEDGMENTS}

We are grateful to Gabriele Jarzina and Agnes Otto for excellent technical assistance.

Résumé - Utilisation des techniques d'empreinte génétique pour différencier des isolats de Paenibacillus larvae subsp. larvae. La loque américaine (AFB) est une maladie du couvain d'abeilles causée par la bactérie sporulante Gram-positive Paenibacillus larvae subsp. larvae. Bien que l'AFB représente une menace sérieuse pour l'Abeille domestique dans le monde entier, il n'existe à l'heure actuelle que peu de travaux d'épidémiologie, en particulier d'épidémiologie moléculaire. L'identification d'un agent pathogène est importante pour déterminer la source d'infection, pour reconnaître des souches particulièrement virulentes et pour superviser les programmes de lutte. Les études génétiques permettent de déterminer précisément l'origine d'un agent pathogène et sa mutabilité. Une méthode souvent utilisée pour identifier le génotype des procaryotes est la rep-PCR, dans laquelle des éléments répétitifs particuliers, présents dans le génome de la bactérie, sont amplifiés par une réaction spécifique de PCR. Par le choix approprié des éléments répétitifs et l'utilisation des amorces correspondantes il est possible de caractériser la bactérie par les motifs des bandes spécifiques d'une souche ou d'un sous-type (Fig. 1). Dans ce travail la rep-PCR a été utilisée avec les amorces BOX A1R, MBO REP1 et ERIC pour caractériser le génotype d'isolats de $P$. l. larvae provenant d'épidémies d'AFB de différentes régions d'Allemagne. Les trois amorces ont fourni des motifs de bandes reproductibles. L'analyse par PCR de l'ADN de P. l. larvae avec l'amorce BOX $\mathrm{A} 1 \mathrm{R}$ a donné trois génotypes différents (A, $a$ et $\alpha$ ), tandis que les amorces MBO REP1 et ERIC ont permis chacune de différencier deux génotypes (B et $b$ d'une part, E et $e$ d'autre part) (Fig. 2). Au total on a pu identifier quatre souches génotypiquement différentes : $A B(E), A b(e), a b(e)$ et $\alpha B(E)$ (Fig. 3). Ces quatre génotypes ne sont pas répartis en Allemagne au hasard, mais sont regroupés géographiquement (Fig. 4). Le type $A B$ a été identifié principalement dans la partie occidentale de l'Allemagne, alors que les type $a b$ et $A b$ prédominent dans la partie orientale. Le type $\alpha B$ n'a pu être mis en évidence que dans un seul cas d'AFB dans le nord de l'Allemagne. Une analyse de la morphologie des colonies de $P$. l. larvae cultivées sur le milieu CSA (gélose au sang de mouton Columbia) et le classement de ces résultats selon les différents génotypes a montré que le morphotype normal (Type I : couleur gris-blanchâtre, surface granuleuse et forme convexe) est présent dans les groupes $A B, a b$ et $\alpha B$. Environ $25 \%$ des échantillons présentaient un morphotype totalement différent (type II : incolore transparent, surface légèrement brillante, forme totalement plate). Ce type peut être assigné au génotype $a b$. Puisque les classifications phénotypiques ont une pertinence limitée, d'autres études devront montrer si cette assignation reste valable. Nos recherches montrent qu'il est possible et significatif d'établir une épidémiologie moléculaire de $P$. l. larvae en se basant sur la méthode de rep-PCR avec l'utilisation des amorces BOX A1R et MBO REP1. On a réussi pour la première fois à classer les populations de $P$. l. larvae présentes en Allemagne en souches génétiquement différenciables, ce qui crée des bases pour des travaux ultérieurs d'épidémiologie de $P$. l. larvae. On peut maintenant étudier si ces différentes souches ont des virulences variables.

loque américaine / Paenibacillus larvae subsp. larvae / empreinte génétique / épidémiologie moléculaire / identification génétique

\section{Zusammenfassung - Anwendbarkeit von DNA- fingerprinting Techniken zur Differenzierung von Feldisolaten von Paenibacillus larvae subsp. larvae. Die Amerikanische Faulbrut (AFB) ist eine bakterielle Erkrankung der Bienenbrut, die durch Paenibacillus larvae subsp. larvae, ein sporenbil- dendes, Gram-positives Bakterium, verursacht wird. Obwohl AFB weltweit eine ernsthafte Bedrohung der Honigbiene darstellt, gibt es bisher erst wenige Arbeiten zur Epidemiologie, speziell zur Molekularepidemiologie, dieser Erkrankung. Die Typisierung eines Krankheitserregers ist wichtig, um die Infektionsquelle zu identifizieren, unterschiedlich virulente Stämme zu erkennen und Bekämpfungsprogramme zu überwachen. Geneti- sche Untersuchungen ermöglichen in besonderem Maße, die Herkunft eines epidemieerzeugenden Agens und seine Mutabilität über Genomanalysen genau $\mathrm{zu}$ bestimmen. Eine häufig angewandte Methode zur Genotypisierung von Prokaryonten ist die rep-PCR, bei der bestimmte, im bakteriellen Genom vorkommende, repetitive Elemente über}


eine spezifische PCR-Reaktion amplifiziert werden. Durch die Wahl geeigneter repetitiver Elemente und die Verwendung entsprechender Primer ermöglichen stamm- oder subtypspezifische Bandenmuster eine Typisierung (Abb. 1). In dieser Arbeit wurde die rep-PCR unter Verwendung der Primer BOX A1R, MBO REP1 und ERIC angewendet, um Feldisolate von $P$. l. larvae zu genotypisieren. Alle drei verwendeten Primer lieferten reproduzierbare Bandenmuster. Die PCRAnalyse von P. l. larvae-DNA mit BOX A1R-Primern ergab drei verschiedene Genotypen (A, $a$, und $\alpha$ ), wogegen MBO REP1- und ERIC-Primer die Unterscheidung von jeweils zwei Genotypen $(B$ und $b$, bzw. $E$ und $e$ ) erlaubte (Abb. 2). Insgesamt konnten bisher vier genotypisch unterscheidbare Stämme identifiziert werden: $A B(E), A b(e), a b(e)$ und $\alpha B(E)$ (Abb. 3). Die vier identifizierten Genotypen finden sich nicht zufällig verteilt in Deutschland, sondern zeigen eine interessante geographische Clusterbildung (Abb. 4). Der Typ $A B$ wurde bisher hauptsächlich im westlichen Teil Deutschlands als Verursacher von AFB-Ausbrüchen identifiziert, wogegen die Typen $a b$ und $A b$ im östlichen Teil vorherrschen. Der Typ $\alpha B$ konnte bislang in lediglich einer AFB-Probe aus dem Norden Deutschlands nachgewiesen werden. Eine Analyse der Morphologie der auf Columbia-Schafblutagar gewachsenen $P . \quad l$. larvae-Kolonien und anschließende Zuordnung dieser Ergebnisse zu den verschiedenen Genotypen ergab, dass der normale Morphotyp (Typ I: grau-weißliche Farbe, rauh-körnige Oberfläche und leicht konvexer Querschnitt) in den Gruppen $A B, A b$ und $\alpha B$ gefunden wird. Ungefähr $25 \%$ der Proben wiesen einen auffällig anderen Morphotyp (Typ II: farblos-gläsern, leicht glänzende Oberfläche, völlig flacher Querschnitt) auf. Dieser Typ kann nach den bisherigen Erkenntnissen dem Genotyp $a b$ zugeordnet werden. Da phänotypische Klassifizierungen in ihrer Aussagekraft limitiert sind, werden weitere Untersuchungen zeigen müssen, ob diese Zuordnung Bestand hat.

Unsere Untersuchungen zeigen, dass es möglich und sinnvoll ist, eine Molekularepidemiologie von P. l. larvae basierend auf der Methode der rep-PCR unter Verwendung der Primer BOX A1R und MBO REP1 zu etablieren.. Es ist mit unseren Arbeiten erstmals gelungen, die in Deutschland verbreitete $P$. $l$. larvae-Population in genetisch unterscheidbare Stämme zu klassifizieren. Damit ist die Grundlage geschaffen für weiterführende Arbeiten zur Epidemiologie von P. l. larvae. Auch die Frage der möglicherweise unterschiedlichen Virulenz verschiedener $P$. l. larvae-Stämme kann nun bearbeitet werden.

Amerikanische Faulbrut / Paenibacillus larvae larvae / DNA-fingerprinting / genetische Typisierung / molekulare Epidemiologie

\section{REFERENCES}

Alippi A.M., Aguilar O.M. (1998) Characterization of isolates of Paenibacillus larvae subsp. larvae from diverse geographical origin by the polymerase chain reaction and BOX primers, J. Invertebr. Pathol. 72, 21-27.

Chantawannakul P., Dancer B.N. (2001) American foulbrood in honey bees, Bee World 82, 168180.

Djordjevic S.P., Ho-Shon M., Hornitzky M.A. (1994) DNA restriction endonuclease profiles and typing of geographically diverse isolates of Bacillus larvae, J. Apic. Res. 33, 95-103.

Djordjevic S.P., Forbes W.A., Smith L.A., Hornitzky M.A. (2000) Genetic and biochemical diversity among isolates of Paenibacillus alvei cultured from Australian honeybee (Apis mellifera) colonies, Appl. Environ. Microbiol. 66, 10981106.

Dobbelaere W., de Graaf D.C., Peeters J.E., Jacobs F.J. (2001) Development of a fast and reliable diagnostic method for American foulbrood disease (Paenibacillus larvae subsp. larvae) using a 16S rRNA gene based PCR, Apidologie $32,363-370$.

Govan V.A., Allsopp M.H., Davison S. (1999) A PCR detection method for rapid identification of Paenibacillus larvae, Appl. Environ. Microbiol. 65, 2243-2245.

Hansen H., Brodsgaard C.J. (1999) American foulbrood: a review of its biology, diagnosis, and control, Bee World 80, 5-23.

Heyndrickx M., Vandemeulebroecke K., Hoste B., Janssen P., Kersters K., De Vos P., Logan N.A., Ali N., Kerkeley R.C. (1996) Reclassification of Paenibacillus (formerly Bacillus) pulvifaciens (Nakamura 1984) Ash et al., 1993, a later subjective synonym of Paenibacillus (formerly Bacillus) larvae (White 1906) Ash et al., 1994, as a subspecies of $P$. larvae, with emended descriptions of $P$. larvae as $P$. larvae subsp. larvae and P. larvae subsp. pulvifaciens, Int. J. Syst. Bacteriol. 46, 270-279.

Hornitzky M.A.Z., Clark S. (1991) Culture of Bacillus larvae from bulk honey samples for detection of American Foulbrood, J. Apic. Res. 30, 13-16.

Hulton C.S.J., Higgins C.F., Sharp P.M. (1991) ERIC sequences: a novel family of repetitive elements in the genomes of Escherichia coli, Salmonella typhimurium and other enterobacteria, Mol. Microbiol. 5, 825-762.

Jelinski M. (1985) Some biochemical properties of Bacillus larvae White, Apidologie 16, 6976.

Martin B., Humbert O., Camara M., Guenzi E. Walker J., Mitchell T., Andrew P., Prudhomme M., Alloing G., Hakenbeck R., Morrison D.A., Boulnois G.J., Claverys J.-P. (1992) A highly conserved repeated DNA element located in the 
chromosome of Streptococcus pneumoniae, Nucl. Acids Res. 20, 3479-3483.

Olive D.M., Bean P. (1999) Principles and applications of methods for DNA-based typing of microbial organisms, J. Clin. Microbiol. 37, 1661-1669.

Plagemann O. (1985) Eine einfache Kulturmethode zur bakteriologischen Identifizierung von Bacillus larvae mit Columbia-Blut-Schrägagar, Berl. Münch. Tierärztl. Wschr. 98, 61-62.

Ritter W. (1996) Diagnostik und Bekämpfung von Bienenkrankheiten, Gustav Fischer Verlag, Jena.

Stern M.J., Ames G.F.L., Smith N.H., Robinson E.C., Higgins C.F. (1984) Repetitive extragenic palindromic sequences: a major component of the bacterial genome, Cell 37, 1015-1026.

Versalovic J., Schneider M., de Bruijn F.J., Lupski J.R. (1994) Genomic fingerprinting of bacteria using repetitive sequence-based polymerase chain reaction, Methods Mol. Cell. Biol. 5, 2540. 